\title{
Kuidun sulatuskinetiikan määritysmenetelmät
}

Arja Seppälä, Seppo Ahvenjärvi, Aila Vanhatalo ja Pekka Huhtanen

MTT/KEL/Eläinravitsemus, 31600 Jokioinen; arja.seppala@mtt.fi; seppo.ahvenjarvi@mtt.fi; aila.vanhatalo@mtt.fi; pekka.huhtanen@mtt.fi

\section{Johdanto}

Rehujen kuiva-aine aine voidaan jakaa solunsisällysaineisiin ja solunseinämäaineisiin eli kuituun (Van Soest 1967). Tämä jako on perusteltua eläinten ruuansulatusfysiologian kannalta. Solunsisällysaineita eläimen omat ruuansulatusentsyymit pilkkovat hyvin, sen sijaan kuitu sulaa ainoastaan mikrobisulatuksen avulla joko etumahoissa tai umpi- ja paksusuolessa. Rehuanalytiikassa jako solunsisällysaineisiin ja solunseinämäaineisiin tehdään neutraalidetergenttikuituanalyysillä. Solunsisällysaineet liukenevat neutraalidetetergenttiin, kuitu ei. Neutraalidetergenttikuitu (NDF-kuitu) kuvaa rehun solunseinämäaineksen kokonaismäärää lukuunottamatta pektiiniä. (Van Soest 1994, suomeksi kuidusta on kirjoittanut mm. Huhtanen 2003).

Solunsisällysaineiden todellinen sulavuus lypsylehmän ruuansulatuskanavassa on lähes $100 \%$ tavallisilla dieeteillä (Van Soest 1967). Näin ollen lypsylehmän rehujen sulavuuden vaihtelusta tavanomaisilla dieeteillä suurin osa on peräisin kuidun osuudesta dieetissä sekä kuidun sulavuuden vaihtelusta. Rehun omista ominaisuuksia kuidun sulavuuteen vaikuttavat potentiaalinen kuidun sulavuus sekä potentiaalisesti sulavan kuidun sulatusnopeus. Potentiaalinen kuidun sulavuus on teoreettinen maksimi, johon päästäisiin, jollei aika rajoittaisi sulatusta (Mertens 1993).

Kuidun sulavuuteen vaikuttavat rehuperäisten ominaisuuksien ohella mm. ruokintataso ja helppoliukoisten hiilihydraattien osuus dieetissä. Dynaamisilla rehuarvojärjestelmillä pystytään huomioimaan tällaisten tekijöiden vaikutus sulavuuteen aiempia faktoriaalisia järjestelmiä paremmin. Dynaamisissa rehuarvojärjestelmissä tarvitaan tietoa rehujen sulatusnopeuksista, pelkkä tieto jossain ruokintatilanteessa toteutuneesta sulavuudesta ei enää riitä. Kuidun sulatuksesta suurin osa tapahtuu pötsissä, ruuansulatuskanavan loppuosan kuidun sulatuksella ei ole paljoa merkitystä tavanomaisilla ruokinnoilla (Huhtanen ym. 1995). Tämän vuoksi pyritään mittaamaan kuidun sulatusnopeutta pötsissä. Kuidun sulatusnopeuden määrittämiseksi käytössä olevia menetelmiä ovat in vivo -kokeiden ohella in situ -menetelmä eli nailonpussiuitot pötsissä sekä in vitro -menetelmät, joissa rehua hajotetaan koeputkessa joko pötsimikrobiymppien avulla tai entsymaattisesti. In vitro -menetelmiin kuuluu myös fermentaatiossa vapautuvien kaasujen tilavuuden mittaamiseen perustuva in vitro -tekniikka, joka on hieman harhaanjohtavasti nimetty in vitro -kaasuntuotantomenetelmäksi, vaikka kyseessä on siis mittausmenetelmä eikä tuotantomenetelmä. Kaasuntuotannon mittaamisen automatisointi on tehnyt siitä kilpailukykyisen menetelmän sulatuskinetiikan määrittämisessä.

\section{In vivo-kokeet}

Eläinkokeista, joissa on mitattu syödyn kuidun määrä, sonnassa eritetyn kuidun määrä, sekä pötsin tyhjennyksen avulla mitattu pötsin kuitupoolin koko, voidaan laskea dieetin keskimääräinen sulatusnopeus (Robinson ym. 1987). Kuitenkaan dieetin useampia rehuja ei voida erottaa toisistaan. Näin ollen väkirehujen kuidun sulatuskinetiikan määrittäminen ei ole mahdollista, sillä niitä ei voida syöttää märehtijälle ainoana rehuna. Menetelmällä ei myöskään saada mitään käsitystä rehun sulatusnopeuden ajallisesta riippuvuudesta. Lisäksi menetelmä on kovin työläs pötsintyhjennysten vuoksi. In vivo määrityksien tuloksia rehun sulatusnopeuksista onkin varsin rajallisesti käytettävissä.

\section{In situ -menetelmä}

In situ -menetelmästä käytetään myös nimityksiä in sacco -menetelmä tai nailonpussi, dacronpussi tai polyesteripussi -menetelmä. Menetelmässä rehunäytettä punnittaan synteettiseen huokoiseen pussiin, joka laitetaan pötsifistelin kautta pötsiin tietyksi ajaksi. Menetelmää on kehitetty jo 1930-luvulta lähtien, ja koska menetelmä on in vivo -kokeisiin verrattuna halpa, nopea ja antaa rehukohtaisia mittaustuloksia, on sitä käytetty runsaasti rehun kuiva-aineen, valkuaisen, kuidun ja myös tärkkelyksen sulatuksen tutkimiseen. Kun halutaan tietoa rehun sulatuskinettiikasta, jokaista aikapistettä varten tarvitaan oma näytepussi, ja peräkkäisten aikapisteiden tulokset muodostavat aikasarjan. Ørskov ja McDonald (1979) sovittivat yhtälön $\mathrm{p}=\mathrm{a}+\mathrm{b}\left(1-\mathrm{e}^{\mathrm{ect}}\right)$ valkuaisen nailonpussihajoavuusaikasarjaan. He myös edelleen yhdistivät havaintoihin virtauskinetiikan vaikutuksen ja laskivat näin rehun valkuaiselle efektiivisen pötsisulavuuden. Nailonpussimenetelmä on ollut perustana useissa märehtijöiden rehujen valkuaisenarviointijärjestelmissä, ja sen vuoksi menetelmän ongelmiin on kiinnitetty runsaasti 
huomiota. Menetelmällä saatuihin tuloksiin vaikuttavat lukuisat seikat, kuten pussin huokoskoko, rehunäytteen partikkelikoko, näytteen painon ja pussin pinta-alan välinen suhde, rehupartikkeleiden mikrobikontaminaatio, pussin pesutapa, pussin sijainti pötsissä, partikkelihävikki, ja pienempi mikrobikolonisaatio pussin sisällä kuin muussa pötsin sisällössä. Eri laboratorioiden välisten tulosten vertailtavuuden parantamiseksi on tehty ehdotuksia menetelmän standardisoimiseksi. Uusimpia in situ -menetelmästä tehtyjä kirjallisuuskatsauksia ovat kirjoittaneet mm. Michalet-Doreau ja Ould-Bah (1992), Huntington ja Givens (1995), Vanzant ym. (1998), Offner ym. (2003).

Tutkijoiden mielipiteet nailonpussimenetelmän käyttökelpoisuudesta sulatuskinetiikan määrittämiseen vaihtelevat (Mertens 1993). Kinetiikkaparametreja määritettäessä edellä mainittujen tekijöiden lisäksi eläimen dieetillä ja ruokinnasta kuluneella ajalla voi olla vaikutusta tuloksiin (Mertens 1993). Vakavin ongelma lienee kuitenkin se, että useissa kokeissa in situ-menetelmä on selvästi aliarvionut kuidun sulatusnopeuden verrattuna in vivo-tuloksiin. Pötsintyhjennyksellä määritetty kuidun sulatusnopeus oli 1,20 - 2,58 kertainen in situ -tulokseen verrattuna (tulokset 5 kokeesta, 16 dieetistä, Huhtanen 1997), lisäksi Huhtasen ym. (1995) kokeessa in situ -menetelmä ei osoittautunut kovin herkäksi määritettäessä eroja kuidun sulatuskinetiikassa.

\section{In vitro -menetelmät, in vitro -kaasuntuotanto}

In vitro -menetelmissä jäljitellään pötsin sulatustapahtumia koeputkessa. Rehunäytettä inkuboidaan kasvatusliuoksessa, johon on lisätty pötsinesteinokulantti. Pötsinesteinokulantin sijasta voidaan periaatteessa käyttää myös kuitua pilkkovia entsyymejä, mutta sulatuskinetiikan määrittämisessä tämä ei ole ollut tavallista. Pötsinesteinokulanttia käytettäessä olosuhteet pyritään pitämään mahdollisimman anaerobisina. Sulatuksen määrä selvitetään joko mittaamalla lopputuotteen määrää (VFA, kaasu) tai mittaamalla hajoamatta olevan lähtöaineen määrää (esim. selluloosa, NDF-kuitu). Kun halutaan arvio rehun sulatusnopeudesta, tarvitaan yleensä jokaista aikapistettä varten oma näytteensä. Tällöin näytteiden lukumäärä nousee nopeasti, mikä rajoittaa menetelmän käytettävyyttä haluttaessa tarkka käsitys rehun sulatuskinetiikasta. In vitro -kaasuntuotannossa mitataan käymisessä vapautuvan kaasun määrää, ja näin kaikki aikapisteet voidaan mitata samasta näytteestä. Kun lisäksi kaasuntuotannon mittauksen automatisoinnin mahdollistavaa tekniikkaa on tullut tarjolle, menetelmä on yleistynyt nopeasti pötsin sulatustapahtumien mallintamisessa ja rehujen sulatuskinetiikan määrittämisessä.

In vitro -kaasuntuotantomenetelmä perustuu siihen, että käymisessä hajotetun orgaanisen aineen määrä korreloi käymisessä vapautuneen kaasumäärän kanssa. Kaasuntuotanto mitattiin aluksi manuaalisesti, mutta sittemmin on kehitetty useita automatisoituja laitteita kaasuntuotannon mittaamiseen (Getachew ym. 1998, Williams 2000). Automatisoidut laitteet mahdollistavat suuren määrän mittauksia ja antavat näin ollen yksityiskohtaisen kuvan rehunäytteen sulatuskinetiikasta. MTT:n Eläinravitsemuksen tutkimusalalla on kehitetty automatisoitu kaasuntuotantolaitteisto vuosina 19961997. Siinä on 39 pullopaikkaa lämpötilakontrolloidussa huoneessa. Kuhunkin 120 ml:n pulloon punnittaan $0,5 \mathrm{~g}$ näytettä ja lisätään $67 \mathrm{ml}$ puskuriliuosta ja $13 \mathrm{ml}$ suodatettua pötsinestettä (kahdelta pötsifistelöidyltä lehmältä) sekä sekoitussauva. Haluttaessa selvittää kuidun sulatuskinetiikkaa näytteenä on rehun NDF-kuitu, eli rehunäytteestä on pesty neutraalidetergentin avulla pois solunsisällysaineet. Pulloihin juoksutetaan hiilidioksidia hapen syrjäyttämiseksi, ja ne kytketään mittauslaitteistoon. Laitteiston paineanturit seuraavat paineenmuutoksia pulloissa. Kun ylipaine pullossa saavuttaa rajaarvon $2.8 \mathrm{kPa}$, magneettiventtiilit avautuvat hetkeksi vapauttaen kertyneen kaasun. Laitteisto seuraa paineen muutoksia jatkuvasti. Laitteisto tallentaa tietokantaan 15 minuutin välein kumulatiivisen kaasumäärän, joka on laskettu paineen muutoksista ja venttiilien avautumiskertojen lukumääristä huomioiden lisäksi pullojen kaasutilavuudet. Mittauksia jatketaan 72 tunnin ajan, koko inkubaation ajan lämpötila huoneessa on $39^{\circ} \mathrm{C}$. Magneettisekoitus on jaksottaista (sekoitus 15 s., tauko $30 \mathrm{~s}$.).

Kaasuntuotantomittauksesta saadaan kullekin näytepullolle kumulatiivinen kaasukäyrä. Sellaisenaan kaasukäyrä ei vielä ole helposti tulkittavissa, eikä siten kovin käyttökelpoinen tulos. Dynaamisessa lehmämallissa käyttökelpoinen tulos on ajan suhteen vakio sulatusnopeus (sulatusnopeus ilmaistaan osuutena jäljellä olevasta sulavasta materiaalista). Tähän pääsemiseksi kaasukäyrälle tehdään tarvittavia laskutoimituksia. Ensin kaasukäyrään sovitetaan SAS-tilasto-ohjelman NLIN-proseduurilla Gompertzin yhtälö, jossa paremman sovitustuloksen saamiseksi poolien lukumäärä on kerrottu kahdella (poolit hakasuluissa):

Kaasumäärä $=[\mathrm{V} 1 * \operatorname{Exp}(-\operatorname{Exp}(\mathbf{1}+\mathrm{k} 1 *(\mathrm{~L} 1-\mathrm{hr})))]+[\mathrm{V} 2 * \operatorname{Exp}(-\operatorname{Exp}(\mathbf{1}+\mathrm{k} 2 *(\mathrm{~L} 2-\mathrm{hr})))]$,

Pötsimallissa poolit ovat väheneviä, eivät kasvavia. Siksi pötsimallissa poolin koko on Gompertzin yhtälön poolin asymptootin ja poolin arvon välinen erotus ja hetkellinen sulatusnopeus $\left(\mathrm{k}_{\mathrm{d}}\right)$ on pooli- 
koon muutos suhteessa poolin kokoon. Seuraavaksi poolien sulatusnopeudet siirretään lähtötiedoiksi Powersim-ohjelmalla tehtyyn pötsimalliin (kuva 1). Mallilla simuloimalla saadaan huomioitua virtauksen vaikutus toteutuneeseen sulatukseen, mitä muutoin olisi hankala huomioida in vitro -menetelmällä. Pötsimallisimulaation tuloksena saadaan potentiaalisesti sulavan kuidun sulavuus mallin oletuksia vastaavassa tilanteessa. Dynaamista lehmämallia varten tästä edelleen lasketaan ajan suhteen vakio sulatusnopeus, joka samalla pötsimallilla samoilla virtauskinetiikan arvoilla antaisi saman sulavuusestimaatin kuin ajan suhteen vaihtuva sulatusnopeus.

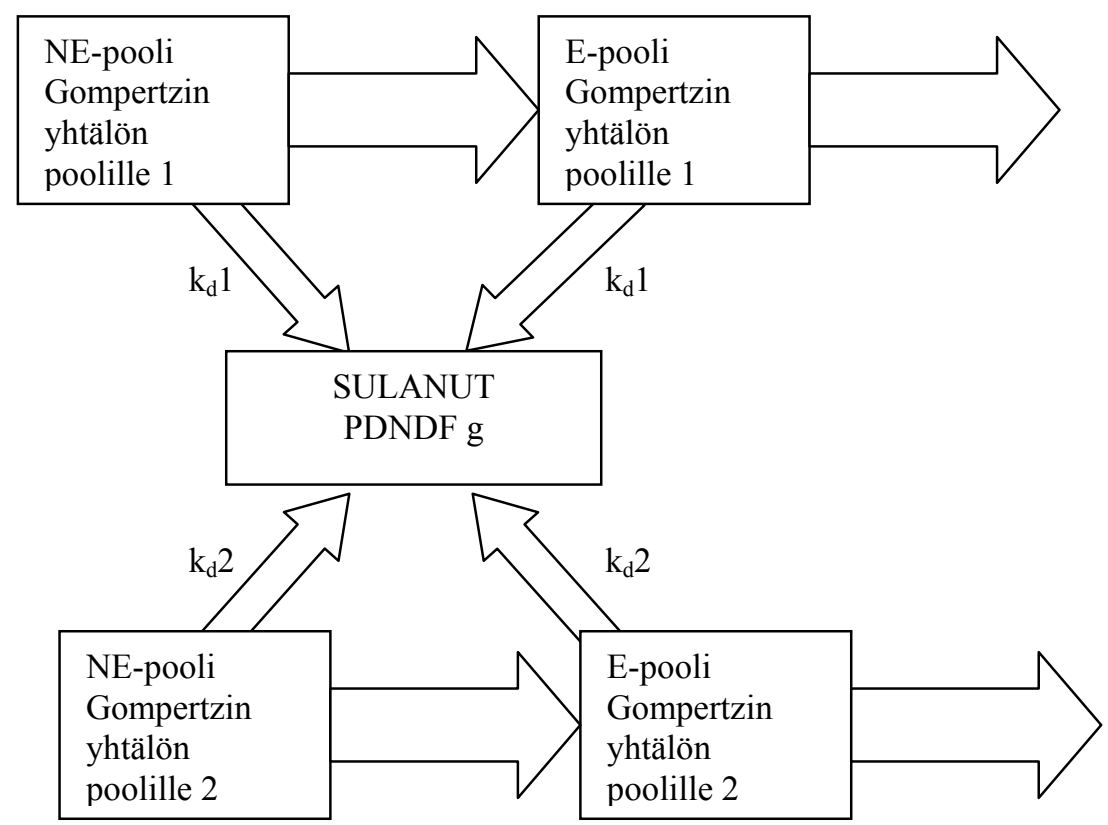

Kuva 1. Pötsimalli, jolla simuloidaan sulavuus käyttäen in vitro -kaasuntuotantomenetelmällä määritettyä ajan suhteen vaihtuvaa sulatusnopeutta $\left(\mathrm{k}_{\mathrm{d}} 1 \mathrm{ja} \mathrm{k}_{\mathrm{d}} 2\right)$. Koska kaasukäyrään sovitettiin kahden poolin malli, pitää kummallekin poolille olla mallissa oma puolikkaansa, ja totetutunut sulavuus on näiden summa. Simulaation alkutilanteessa oletetaan, että 1000 g rehun potentiaalisesti sulavaa NDF-kuitua (PDNDF) on jakautunut pötsimallin NE-pooleihin kaasukäyrään sovitettujen poolien suhteessa. NE (non-escapable) -pooleissa oleva rehu ei vielä voi poistua pötsistä, E (escapable) -pooleissa oleva rehu puolestaan voi poistua pötsistä. Virtausnopeupeus NE-poolista E-pooliin on ajasta riippuvaa gamma2-mallin mukaisesti, eli ajanmyötä kasvavaa. Virtaus ulos Epoolista puolestaan on ajansuhteen vakio-osuus jäljellä olevasta E-poolista. Keskimääräiset viipymisajat ovat 20 tuntia NE-poolissa ja 30 tuntia E-poolissa, mikä vastaa rehun viipymisaikaa ylläpitotasolla.

Sulatusnopeusestimaatin lisäksi voidaan laskea koko rehun sulavuus pötsimallin olettamassa tilanteessa. In vitro -kaasuntuotantomittauksien ohella tarvitaan rehun tuhkapitoisuus, NDF-kuitupitoisuus, ja kuidun potentiaalinen sulavuus. Kuidun sulamaton jäännös määritetään 12 vuorokauden nailonpussiuitolla pötsissä, jolloin erotuksena saadaan estimaatti kuidun potentiaaliselle sulavuudelle. Rehun kuidun sulavuus saadaan kertomalla kaasumittauksista simuloitu potentiaalisesti sulavan kuidun sulavuus potentiaalisesti sulavan kuidun osuudella. Orgaanisen aineen näennäinen sulavuus voidaan laskea Lucas -yhtälöllä (Van Soest 1967), jossa negatiivinen leikkauspiste vastaa sonnan metabolista ja endogeenista ainesta. Kun lisäksi huomioidaan orgaanisen aineen pitoisuus rehussa ja kuidun osuus rehussa, saadaan laskettua estimaatti rehun orgaanisen aineen sulavuudelle (Huhtanen ym. 2001).

In vitro -kaasuntuotantomenetelmällä pyritään mittaamaan sulatusnopeus, jota rajoittavat ainoastaan rehuperäiset tekijät. Tällöin olosuhdetekijät, kuten $\mathrm{pH}$, anaerobisuus, hapetus-pelkistys potentiaali, mikrobien määrä ja niille välttämättömät ravintoaineet pyritään säätämään niin, että ne eivät rajoita sulatusta. Lisäksi kun halutaan mitata rehun kemiallisten komponenttien sulatusnopeutta, rehunäytteen tulee olla riittävän hienoksi jauhettua (Mertens 1993). Menetelmän käytännön toimivuuden ja toistettavuuden takia monia ilmiöitä, kuten märehtimistä, ravintoaineiden imeytymistä, rehupartikkeleiden virtausta ulos pötsistä taikka uuden rehun syöntiä, ei voida jäljitellä laboratorio-oloissa. Näitä puutteita voidaan kuitenkin korjata mallinnuksen avulla, kuten pötsisimulaatiolla, jolla huomioidaan virtauksen vaikutus. 
Edellä kuvatulla tavalla Huhtanen ym. (2001) ennustivat 15 eri kehitysasteella korjatun timoteinurminatasäilörehun (rehut kolmelta eri vuodelta kesän ensimmäisestä sadosta) NDF-kuidun sulavuuden hyödyntäen tuloksia kaasuntuotannon mittauksista ja 12 vuorokauden nailonpussiuitoista. Edelleen ennustettiin myös rehujen orgaanisen aineen sulavuudet käyttäen Lucasin yhtälöä solunsisällysaineille. Ennustetun ja in vivo -kokeissa mitatun orgaanisen aineen sulavuuden välinen yhteys oli erinomainen (in vivo $=-7,4 \mathrm{~g} / \mathrm{kg}+1.003 \cdot$ ennuste, $\mathrm{R}^{2}=0.99$; ennustevirhe $8,5 \mathrm{~g} / \mathrm{kg}$ ). Samoin NDFkuidun sulavuuden osalta ennuste oli myös erinomainen (in vivo $=1,2 \mathrm{~g} / \mathrm{kg}+0.999$.ennuste, $\mathrm{R}^{2}=0,987$; ennustevirhe $9,3 \mathrm{~g} / \mathrm{kg}$ ). Nämä tulokset osoittavat että in vitro -kaasuntuotantomenetelmä yhdistettynä kuidun potentiaalisen sulavuuden määritykseen nailonpussiuitolla, on lupaava menetelmä kuidun sulatuskinetiikan määrityksessä. Menetelmän etuja ovat lisäksi edullisuus ja nopeus verrattuna in vivo -kokeisiin. Pötsifistelöityjä eläimiä ei myöskään tarvita samassa määrin kuin nailonpussimenetelmässä tai in vivo -kokeissa. Lisäksi menetelmä on monilta osin standardisoitavissa, tosin tällä hetkellä erilaisia laitteistoja on maailmalla käytössä useita ja tulosten hyödyntämisen tapa ja aste vaihtelevat. Erityisesti on huomionarvoista, että menetelmä soveltuu myös väkirehujen kuidun sulatuskinetiikan arviointiin, mikä on in vivo -kokeissa mahdotonta. In vitro -kaasuntuotantomenetelmällä voidaan lisäksi tutkia erilaisten prosessointien ja käsittelyjen vaikutusta sulatuskinetiikkaan, sekä myös solunsisällysaineiden sulatuskinetiikkaa.

Getachew, G., Blummel, M., Makkar, H.P.S. \& Becker, K. 1998. In vitro gas measuring techniques for assessment of nutritional quality of feeds: a review. Anim. Feed Sci. Technol. 72: 261-281.

Huhtanen, P. 1997. Methods in assessing the parameters of digestion and passage kinetics in the rumen and utilisation of these parameters in digestion models. Julkaisussa: In vitro and in vivo methods used in experiments on digestion processes and feed evaluation: international seminar: 3-4 October 1996, Balice near Krakow, Poland. Toim. A. Antoniewicz \& K. Sokol. p. 89-98.

Huhtanen, P. 2003. Kuidun ja sen laadun merkitys lypsylehmien ruokinnassa. Maito ja me 6: 18-19.

Huhtanen, P., Jaakkola, S. \& Kukkonen, U. 1995. Ruminal plant cell wall digestibility estimated from digestion and passage kinetics utilizing mathematical models . Anim. Feed Sci. Technol. 52: 159-173.

Huhtanen, P., Ots, M., Ahvenjärvi, S. \& Rinne, M. 2001. Prediction of the in vivo digestibility of grass silage from gas production kinetics. Julkaisussa: Joint Meeting of the American Dairy Science Association: Proceedings of the 54th Annual Reciprocal Meat Conference, Volume II. J. Dairy Sci. 84, Supplement 1: 197. (Abstracts 817).

Huntington, J.A. \& Givens, D.I. 1995. The in situ technique for studying the rumen degradation of feeds: a review of the procedure. Nutrition Abstracts and Rewiews (Series B) 65 (2), 63-93.

Mertens, D.R. 1993. Rate and extend of digestion. Julkaisussa: Quantiteve aspects of ruminant digestion and metabolism. Toim. J.M. Forbes \& J. France, s. 13-51.

Michalet-Doreau, B. \& Ould-Bah, M.Y. 1992. In vitro and in sacco methods for the estimation of dietary nitrogen degradability in the rumen: a review. Anim. Feed Sci. Technol. 40: 57-86.

Offner, A., Bach, A. \& Sauvant, D. 2003. Quantitative review of in situ starch degradation in the rumen. Anim. Feed Sci. Technol. 106: 81-93.

Orskov, E.R. \& McDonald, I. 1979. The estimation of protein degradability in the rumen from incubation measurements weighted according to rate of passage. J. Agric. Sci. Camb. 92: 499 -503.

Robinson, P.H., Tamminga, S. \& Van Vuuren A.M. 1987. Influence of declining level of feed intake and varying the proportion of starch in the concentrate on rumen ingesta quantity, composition and kinetics of ingesta turnover in dairy cows. Livest. Prod. Sci. 17:37-62.

Vanzant, E.S., Cochran, R.C. \& Titgemeyer, E.C. 1998. Standardization of in situ techniques for ruminant feedstuff evaluation. J. Anim. Sci. 76: 2717-2729.

Van Soest, P.J. 1967. Development of a comprehensive system of feed analyses and its application to forages. J. Anim. Sci. 26: 119-128.

Van Soest, P.J. 1994. Nutritional Ecology of the Ruminant. Cornell University Press, New York.

Williams, B.A. 2000. Cumulative gas-production techniques for forage evaluation. Julkaisussa: Forage evaluation in ruminant nutrition. CAB International. Toim. D.I. Givens, E. Owen, R.F.E. Axford \& H.M. Omed. s. 189-213. 